\title{
A koronáriafiziológia nem hyperaemiás indexei
}

\author{
Piróth Zsolt
}

Gottsegen György Országos Kardiológiai Intézet, Budapest

Levelezési cím:

Dr. Piróth Zsolt, Gottsegen György Országos Kardiológiai Intézet, 1096 Bp, Haller u. 29. E-mail: zpiroth@gmail.com

\begin{abstract}
A Fractional Flow Reserve (FFR) méréssel ellentétben „nyugalomban” és nem hyperaemiában végzett intrakardiális fiziológiai vizsgálatok az utóbbi időben a kutatások homlokterébe kerültek. Ezek az ún. nonhyperaemiás nyomáshányadosok (non-hyperemic pressure ratio, NHPR) kissé egyszerübben és gyorsabban, illetve minimálisan olcsóbban meghatározhatók, mint a gold standard FFR. Ugyanakkor minél kevésbé hyperaemiás körülmények között vizsgáljuk a koronáriaszűkületek funkcionális hatását, annál jobban sérül a diagnosztikus pontosság, és a tisztán nyugalomban történt meghatározással az már csak $80 \%$-os. A két nagy betegszámú FFR-t és iFR-t összehasonlító randomizált tanulmány arra enged következtetni, hogy az iFR non-inferior az FFR-hez képest. A jelen összefoglaló felvázolja és kritikusan értékeli az NHPR elméleti alapját, rámutat a fenti két vizsgálat korlátaira és elemzi az NHPR-t az iFR-en túl.

Kulcsszavak: FFR, iFR, nonhyperaemiás, diagnosztikus érték
\end{abstract}

\section{Non hyperemic pressure ratios in coronary physiology}

Lately, non-hyperemic pressure ratios (NHPR) measured "at rest" without the need for hyperemia as opposed to Fractional Flow Reserve (FFR) have taken to central stage in the realm of clinical intracoronary physiology. NHPR are claimed to be easier, quicker and less costly to measure than the gold standard FFR. At the same time, less hyperemia leads to lower diagnostic accuracy, and that of NHPR measured at rest remains only $80 \%$ compared to FFR. Two large-scale randomized clinical trials have shown that iFR is non-inferior to FFR. The present review summarizes and critically analyzes the theoretical basis of NHPR, highlights the limitations of these trials and discusses NHPR beyond iFR.

Keywords: FFR, iFR, non-hyperemic, diagnostic accuracy

A Fractional Flow Reserve (FFR) a koronáriaszűkü-
letek funkcionális súlyosságának meghatározásában
mára aranystandarddá vált (1). Kiterjedt állatkísérletes
és humán validációs, illetve a diagnosztikus vágóér-
tékre vonatkozó tanulmányok (2-6), illetve különböző
kohorszvizsgálatok $(7-15)$ után két nagy randomizált
vizsgálat, a DEFER $(16,17)$ és a FAME (18-20) alapján
2010-ben az Európai Kardiológus Társaság (ESC) mio-
kardiális revaszkularizációra vonatkozó ajánlásában az
FFR-meghatározást I. oszályú indikációval A-eviden-
ciaszinttel jelölte meg, ha a tervezett elektív perkután
koronária-intervenció (PCI) előtt nem áll rendelkezés- re az adott érre vonatkozó, iszkémiát igazoló objektív bizonyíték (21). Az azóta kiadott 2014-es (22), majd a legfrissebb, 2018-as (23) és 2019-es ESC ajánlásban (24) is az FFR-mérés IA indikációval bír. A DEFER-vizsgálat alapján elmondható, hogy FFR-méréssel jól kiválaszthatók azok a léziók, amelyek revaszkularizációja sem prognosztikus, sem tüneti előnnyel nem jár; e tekintetben nagyon megnyugtató az az eredmény, hogy az FFR-mérés alapján nem revaszkularizált szükületek 15 éves távlatban sem járnak csak gyógyszeres kezelés mellett több jelentős, nemkívánatos kardiovaszkuláris eseménnyel (MACE), mint revaszkularizáció 
esetén, sőt az utóbbi csoportban szignifikánsan több a célérrel összefüggő késői, spontán miokardiális infarktus (25). A FAME-vizsgálat alapján pedig elmondható, hogy többér-betegség $\mathrm{PCl}$-vel történő kezelése FFR-vezérléssel kevesebb MACE-szel jár, mint a hagyományos, angiográfiás megítélés alapján végzett $\mathrm{PCl}$. A FAME 2-vizsgálat igazolta, hogy az FFR-méréssel vezetett $\mathrm{PCl}$ a csak gyógyszeres kezeléshez képest szignifikánsan csökkenti a jelentős, nemkívánatos kardiovaszkuláris események előfordulását (26, 27). A nagyszámú bizonyíték és erős ajánlás ellenére azonban az FFR-mérés alkalmazása szinte mindenhol elmarad a kívánatostól és nagyfokú variabilitást mutat (28). Ennek okai összetettek: ismerethiány, környezeti hatás, illetve egyéni magatartás. Az első aligha fontos tényező, mert a nagyszámú publikáció, az Európában 9 éve IA osztályú ajánlás, illetve a rengeteg FFR-ről szóló előadás nyomán nehezen elképzelhető, hogy az FFRrel kapcsolatos alapismeretek hiánya magyarázná az alkalmazás szuboptimális mértékét. A meghatározó ok valószínủleg a harmadik: intervenciós, sőt egész orvosi képzésünk hangsúlyosan morfológiai alapú, a szemünkben, az általunk elvégzett angiográfiában bízva hozzuk meg revaszkularizációs döntéseinket. Ennek megváltoztatása, a funkcionális szemlélet bevezetése sokkalta nehezebb, mint a környezeti tényezők módosítása, ráadásul Magyarországon az FFR-mérés, relatíve kedvező finanszírozása révén, még financiális szempontból is vonzó katéteres labor szinten.

Ugyanakkor a szűkületek funkcionális meghatározásának egyszerüsítése vonzó ötletnek tűnik munkaszervezési szempontból. Ennek egyik elvi lehetősége a nem hyperaemiás FFR, hanem „nyugalmi”, ún. nonhyperaemiás nyomáshányados (non hyperemic pressure ratio, NHPR) meghatározás. Ennek szószólói hangsúlyozzák, hogy az FFR-méréshez szükséges hyperaemia létrehozásához leginkább alkalmazott adenozin így megspórolható, mellékhatásai elkerülhetők, a procedúra lerövidíthető. Az NHPR közül elsőként az „Instantenous Wave-free Ratio”, az iFR került az érdeklődés homlokterébe - bár először a nyugalmi $P_{d} / P_{a}$ hányados és az FFR közti szoros korreláció került leírásra (29).

\section{iFR}

A 2012-ben publikált ADVISE-study (30) két részből állt: az első részben 39 koronáriaszűkületen egyidejü nyomás- és áramlás (Doppler) mérést végeztek, ennek segítségével arra a következtetésre jutottak, hogy a diasztolé egy részében fennálló (a diasztolé 25\%-tól a szisztolé előtt 5 ms-ig) ún. „wave-free” periódusban (WFP) észlelhető intrakoronáriás rezisztencia minimális, állandó és nem különbözik szignifikánsan az intravénás adenozin infúzióval elért maximális hyperaemiástól. A WFP-ben mért disztális koronária átlagnyomás és aorta átlagnyomás hányadosát nevezték el iFR-nak.
A vizsgálat második részében, 118 koronáriaszükületen iFR-t és FFR-t mértek (azaz csak nyomást), és azt a következtetést vonták le, hogy az iFR jól korrelál az FFR-rel. ROC-analízissel megállapították, hogy a 0,80as FFR-vágóértéket alapul véve a legjobb iFR cut-off a 0,83 .

A publikáció élénk vitát eredményezett. A VERIFY multicentrikus vizsgálatba (31) 5 hét alatt 206 konszekutív beteget vontak be. Intravénásan, standard, $140 \mu \mathrm{g} / \mathrm{kg} /$ perc adagú adenozin adásával FFR-t mértek, a mérést néhány perc várakozás után megismételték a reprodukálhatóság lemérésére, majd iFR-t mértek ismételten, végül a fenti dózisú adenozin adásával lemérték a hyperaemiás iFR-t annak tisztázására, hogy az iFR-t tényleg nem befolyásolja-e a hyperaemia. A vizsgálat során megállapították, hogy az ADVISE-vizsgálatban legjobbnak talált 0,83-as iFR-vágóérték diagnosztikus pontossága a 0,80-as FFR-t alapul véve $68 \%$, a vizsgálatban mért átlagosan 0,82-es iFR-érték intravénás adenozin adása mellett 0,64-re csökkent, tehát nem teljesül az a feltételezés, hogy független lenne a hyperaemiától, és bár mindkét index jó reprodukálhatóságot mutatott, az FFR ebből a szempontból is felülmúlta az iFR-t. Az iFR hyperaemia kapcsán fellépő változását mutatja sematikusan az 1. ábra. Mindemellett a VERIFY-vizsgálat igen fontos megállapítása volt az, hogy ROC-analízis alapján az iFR diagnosztikus értéke nem különbözött a nyugalmi, teljes szívciklusban mért átlagos disztális koronáriás és aortás nyomáshányadosétól (nyugalmi $\mathrm{P}_{\mathrm{d}} / \mathrm{P}_{\mathrm{a}}$ ), illetve a nyugalmi transz-sztenotikus nyomásgradiensétöl. A mért adatok arra utaltak, hogy az iFR-t befolyásolja a nyugalmi szívfrekvencia és a vérnyomás is, azaz szemben az FFR-rel, függ az aktuális hemodinamikai állapottól. A fenti megállapításokat megerősítették egy retrospektív, 497 archivált nyomásgörbét felölelő elemzéssel. Az iFR és az FFR közti gyenge korreláció azt jelenti, hogy hasonló nyugalmi nyomásgradienssel (azaz iFR-rel) bíró szükületek hyperaemiás nyomásgradiense (azaz FFR-értéke) jelentősen különbözhet, ami érthető abból a megfontolásból, hogy a szükületen kialakuló nyomáslejtő $(\Delta p)$ két komponensból, egy frikciósból (f) és egy szeparációsból (s) áll, és amíg a frikciós komponens egyenesen arányos az áramlással (Q), addig a szeparációs annak négyzetével arányos, azaz $\Delta \mathrm{p}=\mathrm{fQ}+\mathrm{sQ}$ (32).

Az ADVISE II study (33) vizsgálói a VERIFY-vizsgálat azon megállapítását, hogy gyenge az iFR és az FFR közti korreláció részben, ezt azzal magyarázták, hogy a mérések nem megfelelő, pontos technikával történtek. Azonban amellett, hogy részletes, szigorú kritériumokat adtak mindkét index mérésére, az ADVISE-tanulmánnyal ellentétben itt már a 0,89-es iFR-vágóértéket alkalmazták, illetve hibrid algoritmust (34) javasoltak az adenozin használatának csökkentésére. A szigorú mérésre vonatkozó előírások nyomán a regisztrátumok 25\%-a (!) elemzésre alkalmatlannak bizonyult a core laboratóriumban valamely előzetesen meghatározott kri- 

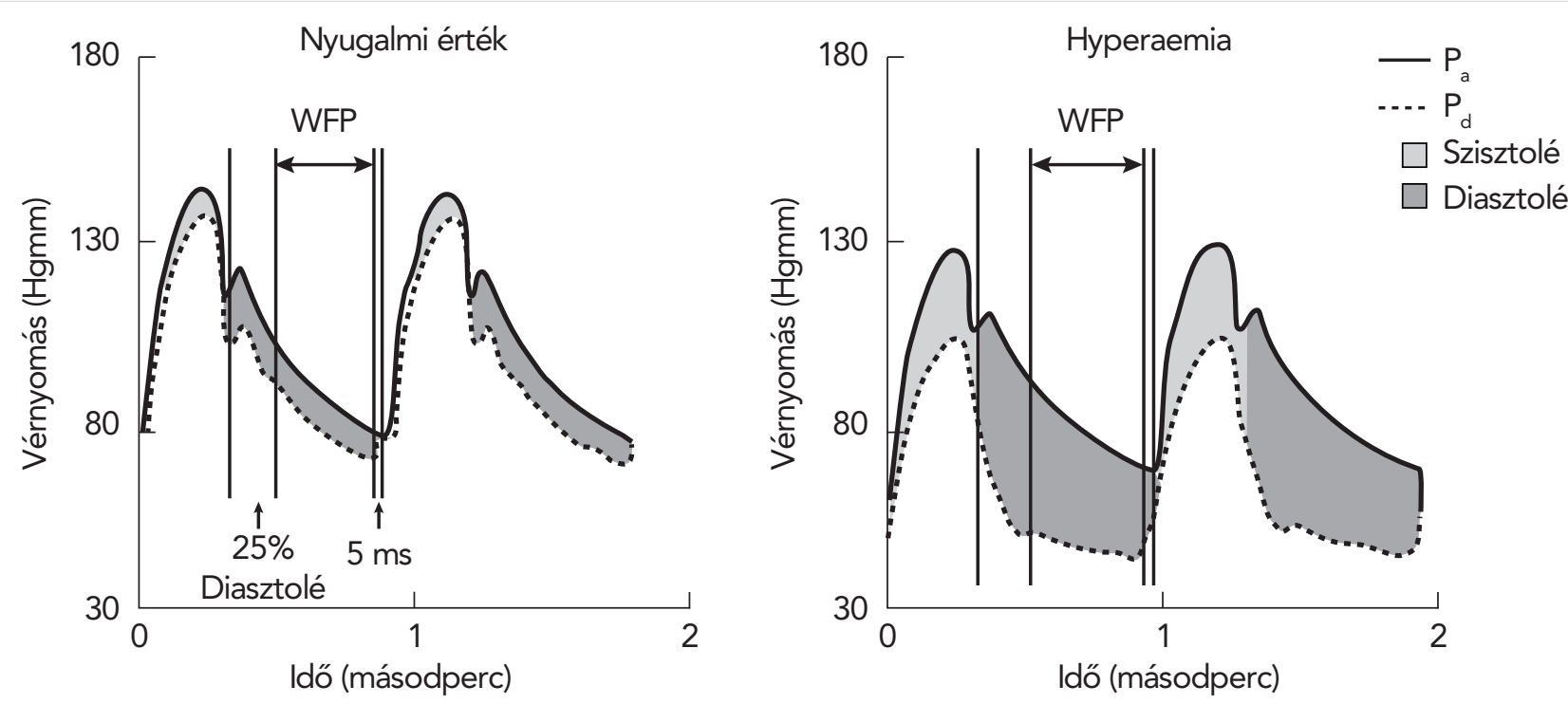

1. ÁBRA. A nyomásgradiens változása sematikusan a nyugalmihoz (REST) képest hyperaemiában (HYPEREMIA) a wave-free periódusban (WFP) (31)

térium alapján, leggyakrabban az iFR mérési ablakát jelentő WFP meghatározásához szükséges EKG-jel hiánya, vagy artefaktuma miatt. Így végül 598 betegben 690 mérés elemzése történt. A hibrid megközelítés lényege az, hogy a cut-off értéket jelentősen meghaladó iFR $(\geq 0,94)$ esetén feltételezi, hogy az FFR negatív lenne, ezért nem alkalmaz adenozint, míg jelentősen a vágóérték alatti iFR $(\leq 0,85)$ esetén pedig azt feltételezi, hogy az FFR pozitív lenne, ezért nem alkalmaz adenozint, és csak 0,86 és 0,93 közötti iFR-értékek esetén történik hyperaemiás (FFR) mérés, azaz adenozin adása a döntéshozatalhoz. Az ADVISE II-vizsgálatban a $\leq 0,85$ iFR-érték 88,1\%-ban, a $\geq 0,94$ iFR-érték 93,1\%-ban adott az FFR-rel egyező információt (azaz pozitív, illetve negatív eredményt), illetve a hibrid algoritmussal ebben a populációban a betegek $65 \%$-ában vált szükségtelenné adenozin adása. ROC-analízissel a legjobb vágóértéknek a 0,89-es iFR-érték bizonyult. $A z$ ez alapján történt pozitív, illetve negatív értékelés 82\%-ban egyezett az FFR alapján történt besorolással (0,80-as cut-off értékkel).

A fenti vizsgálatok nyomán nagyon kérdéses maradt az iFR diagnosztikus pontossága, illetve az, hogy mennyivel pontosabb, mint a nyugalmi $P_{d} / P_{a}$ hányados, amelyet minden FFR konzol a hyperaemia létrehozása előtt minden további software nélkül megad. Ennek tisztázására folytatták le a VERIFY 2-vizsgálatot (35). 197 beteg, 257 középsúlyos (átl. 48\%-os átmérő) szűkületén történt nyugalmi $P_{d} / P_{a}$, iFR, majd FFR és hyperaemiás iFR-meghatározás. Az iFR-nél 0,90-es, a nyugalmi $P_{d} / P_{a}$-nál a 0,92-es bináris cut-off értéket használták és vizsgálták az FFR alapján történt $(0,80$-as vágóérték melletti) döntéshozatallal való egyezést. Emellett kérdés volt, hogy a hibrid stratégia (iFR-nél csak 0,86 és 0,93 között, nyugalmi $P_{d} / P_{a}$-nál csak 0,87 és 0,94 kö- zött adnak adenozint és az alsó érték alatt pozitívnak, a felső felett negatívnak tartják az eredményt) milyen gyakran teszi lehetővé az adenozin elkerülését és milyen diagnosztikus értékkel. A vizsgálat fő megállapításai az alábbiak voltak: a bináris cut-offok alkalmazásával az iFR és a nyugalmi $P_{d} / P_{a}$ FFR-hez képest mért diagnosztikus értéke nem különbözik, mindkettő kb. 20\%-ban az FFR-től eltérő döntéshez vezet (azaz FFR pozitív, nyugalmi index negatív, vagy fordítva), illetve a hibrid algoritmus minkét nyugalmi index esetén kb. 53-54\%-ban teszi lehetővé az adenozin elkerülését, de még a hibrid algoritmus mellett is $10 \%$-ban nem egyezik a nyugalmi index és az FFR alapján történt szignifikanciameghatározás.

A RESOLVE-tanulmányt (36) a korábbiaknál jelentősen több, 1768, beteg bevonásával, 1974 lézión végezték több centrumban, illetve core laboratórium alkalmazásával. A regisztrátumok közel 20\%-a értékelhetetlennek bizonyult a core laboratóriumban, így végül 1593 regisztrátum került elemzésre. Ezek alapján elmondható, hogy a 0,80-as FFR-vágóértéket alapul véve a legjobb iFR cut-off a 0,90, a legjobb nyugalmi $P_{d} / P_{a}$ cut-off a 0,92 volt, a két nyugalmi index diagnosztikus pontossága $80 \%$ volt az FFR-hez képest és nem különbözött egymástól. Minél inkább elvárás a magasabb diagnosztikus pontosság, annál inkább szükséges a hyperaemia, azaz az adenozin adása. Adenozin nélkül a fenti, 80\%-os diagnosztikus pontosság érhető el, ha $90 \%$-ot meghaladó diagnosztikus pontosságra törekszünk, akkor csak 65\%-ban, ha azonban 95\% vagy 99\%-ot meghaladó diagnosztikus pontosság a cél, az adenozin csak 28,6\%, illetve 18\%-ban kerülhető el. Ezt a 2. ábra szemlélteti.

Ezek után a fő kérdés az, hogy van-e klinikai jelentősége az FFR-hez képest csupán $80 \%$-os diagnosztikus 


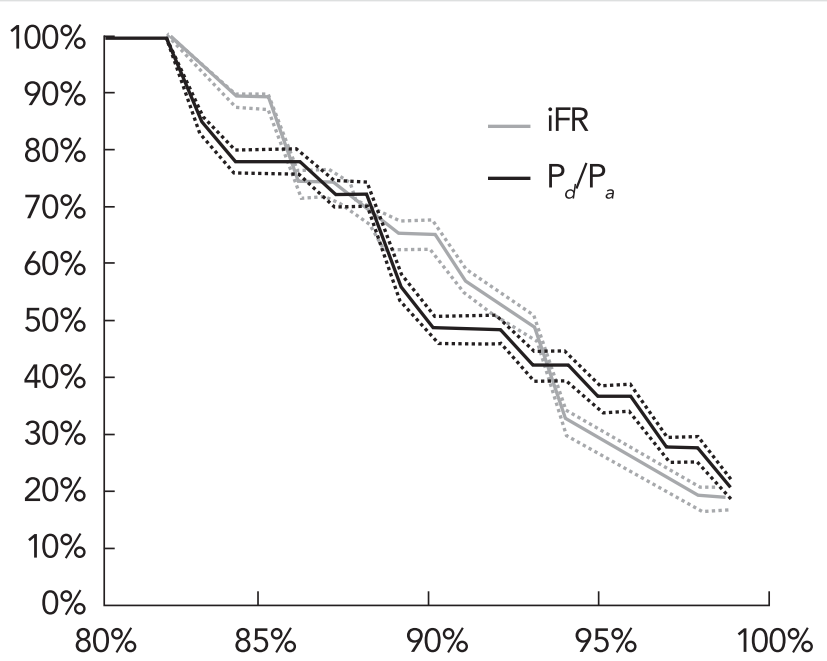

2. ÁBRA. Az adenozin használata (hyperaemia) és a nyugalmi $P_{d} / P_{a}$, illetve iFR diagnosztikus pontossága közti összefüggés (az $x$ tengelyen az FFR-en alapuló döntéshozatallal egyezés mértéke, az y tengelyen az adenozin szükségtelenségének aránya látható) (36)

pontosságnak. Ennek vizsgálatára két nagyon hasonló, klinikai végpontokat elemző, randomizált tanulmányt folytattak le: a DEFINE-FLAIR (37) és az iFR SWEDEHEART (38) studyt.

A DEFINE-FLAIR-vizsgálatba 2492, stabil angina-, vagy stabilizált ACS miatt koronarográfiára került beteget vontak be, akiknél 40-80\%-os szükületet találtak, és ezek funkcionális súlyosságát kívánták meghatározni; a betegeket 1:1 arányban iFR, illetve FFR-mérésre randomizálták. Az előbbi csoport betegeit, amennyiben az iFR 0,89, vagy alacsonyabb volt, revaszkularizálták $\mathrm{PCl}$-vel vagy mútéttel, az ennél magasabb mért iFR esetén csak gyógyszeres kezelést alkalmaztak. Az FFR-csoportban hasonlóan jártak el, de itt a szokásos 0,80-as cut-off FFR-értéket használták. Ebben és az iFR SWEDEHEART-vizsgálatban tehát már nem alkalmazták a hibrid iFR-stratégiát. A DEFINE-FLAIR primer végpontja az egyéves MACE volt, amelybe az összhalálozás, a nem fatális miokardiális infarktusok és a nem tervezett revaszkularizáció tartozott. A vizsgálati hipotézis az volt, hogy az iFR-rel vezetett revaszkularizáció non-inferior az FFR-rel vezetetthez képest és a non-inferioritási margót 3,4\%-ban határozták meg-ez, tekintettel arra, hogy feltételezték, hogy a vizsgált populációban a primer végpont 8,5\%-ban fordul elő, azt jelentette, hogy, ha az FFR-csoportban 8,5\%-os, az iFR-csoportban 11,8\%-os gyakorisággal (azaz az utóbbiban közel 40\%-kal gyakrabban) fordul elő a primer végpont, az iFR még mindig tartható non-inferiornak az FFR-hez képest!

A DEFINE FLAIR-vizsgálat hozta a várt eredményt: az iFR-rel és az FFR-rel vezetett revaszkularizáció melletti egyéves MACE előfordulás nem különbözött (rendre $6,8 \%$ vs. 7,0\%-nak adódott), illetve kimutatták, hogy az
iFR-méréssel az FFR-hez képest átlagosan 4,5 perccel rövidebb a beavatkozás és kevesebb beteg számolt be kellemetlen érzésről a vizsgálat során, ami nyilván az FFR-méréshez alkalmazott adenozin mellékhatásából, illetve annak hiányából származott. Megjegyzendő, hogy az esetek 59\%-ában használtak intravénás adenozin infúziót, 28\%-ában intrakoronáriás adenozin bólust és 13\%-ában egyéb hyperaemiás ágenst.

Az iFR SWEDEHEART a DEFINE-FLAIR-rel teljesen egyező beválasztási kritériumokat, elrendezést, 1:1 arányú iFR-re, illetve FFR-re történt randomizációt és primer végpontot alkalmazott, az FFR-csoportban feltételezetett $8,0 \%$-os primer végpont előfordulás mellett a non-inferioritási margót 3,2\%-ban határozta meg (azaz közel 40\%-kal magasabb primer végpont előfordulás mellett is teljesül a noninferioritás). Bár az iFR-csoportban betegenként szignifikánsan több szükületet vetettek alá mérésnek, mint az FFR-csoportban (a publikáció alapján feltételezhetően azért, mert a vizsgálók az utóbbi csoportban félvén az adenozin mellékhatástól kevésbé követték a vizsgálati protokollt), ennek ellenére az FFR-csoporban szignifikánsan több funkcionálisan jelentős szűkületet találtak és több stentet implantáltak. Az iFR-hez képest az FFR-mérés 2,3 perccel hosszabbította meg a vizsgálatot, és $69 \%$-os intravénás adenozin használati arány mellett ebben a vizsgálatban is szignifikánsan több beteg számolt be (átmeneti) kellemetlenségröl az FFR-csoportban, mint az iFR-karon. $A z$ egyéves primer végpontban nem volt szignifikáns különbség (iFR 6,7\%, FFR 6,1\%, p=0,53).

A DEFINE-FLAIR és az IFR SWEDEHEART tehát több mint 4500 beteg bevonásával igazolta az iFR non-inferioritását az FFR-hez képest a revaszkularizáció vezetésében, klinikai végpontok alapján, és az FFR-rel egyezően IA indikációt kapott az ESC-ajánlásokban (23, 24). A 2019-es TCT-kongresszuson bejelentett kétéves eredmények $(39,40)$, a vártnak megfelelően, hasonlóak voltak. Miért kell mégis fenntartásokkal fogadni ezeket az eredményeket? Ennek döntően négy oka van.

Először is a megelőző vizsgálatok alapján tudjuk, hogy az iFR (és hozzá hasonlóan a másik egyszerü index, a nyugalmi $P_{d} / P_{a}$ hányados is) $80 \%$-os egyezést mutat az FFR-rel. Ha tehát azt kívánjuk vizsgálni, hogy mekkora különbséget eredményez az iFR-en alapuló döntéshozatal az FFR-hez képest, akkor ezt csak a vizsgált populáció kb. 20\%-a mutatja, azaz az észlelt különbség ötödére „hígult”. A döntéshozatalban mutatkozó különbséget akkor lehetne tisztán feltárni, ha csak az iFR-FFR diszkrepanciát (iFR-rel negatív, FFR-rel pozitív a szükület, vagy fordítva) mutató szükületekkel bíró betegeket vonnánk randomizált vizsgálatba. Ennek a jelentőségét aláhúzza, hogy a fötörzs és proximális LAD-szűkületek esetén közel 30\% a diszkrepancia az iFR és az FFR között (41), márpedig ezek a prognosztikailag fontos léziók.

A második fontos limitáció, hogy mindkét vizsgálatba alacsony kockázatú betegek kerültek. Míg a FA- 
ME-vizsgálatban 13\%, a DEFINE-FLAIR-ben $7 \%$ volt az egyéves MACE-arány, az előbbiben 0,71, az utóbbiban 0,83 volt az átlagos FFR, a két studyban a 0,80 alatti FFR-értékek aránya rendre $63 \%$, illetve $35 \%$ volt, a FAME-ben minden beteg (definíció szerint) többér-beteg volt, a DEFINE-FLAIR-ben csak $42 \%$, a posztinfarktusos populáció aránya rendre $37 \%$ vs. $30 \%$ volt, a FAME-ben mindössze $12 \%$ nem került revaszkularizációra, míg az utóbbiban 47\%, illetve a FAME-vizsgálat betegei átlagosan 1,9 stentet kaptak, míg a DEFINE-FLAIR-ben 0,72-t. Alacsony várható rizikó esetén természetesen még nehezebb annak kimutatása, hogy az új (iFR) a régihez (FFR) képest szignifikánsan roszszabb kimenetellel járna. Ennek a szempontnak a jelentőségét az Amerikai Kardiológus Társaság elismerte és figyelmeztetést adott ki (42).

A harmadik fontos kritika a noninferioritási margót érinti: nehéz azt elfogadni, hogy akár közel 40\%-kal magasabb súlyos adverz kardiovaszkuláris eseményráta mellett is nevezhető az iFR-rel vezetett revaszkularizáció non-inferiornak az FFR-rel vezetetthez képest, főleg annak figyelembevételével, hogy a különbséget egy ártalmatlan, átmeneti diszkomforttal járó, és a vizsgálatot 4,5, illetve 2,3 perccel megnyújtó adenozin adása eredményezi. Ha tekintetbe vesszük, hogy a mai magyar gyakorlatban messze dominál az intrakoronáriás adenozin használata az intravénáshoz képest, amely jelentősen lerövidíti a procedúrát és minimalizálja a betegek diszkomfortját, akkor a fenti munkaszervezési és szubjektív különbségek elenyésznek.

A negyedik limitációja a két nagy tanulmánynak pedig az, hogy ha csak a halálozást és a nem fatális infarktusok előfordulását vesszük számba, az iFR-karokon 30\%-kal magasabb ezek előfordulása, mint az FFR-karokon és ez a különbség közel szignifikáns $(p=0,09)$, amely egy relatíve alacsony kockázatú populáció egyéves utánkövetése esetén kissé alarmírozó (43).

\section{Egyéb nonhyperaemiás indexek}

Az iFR alapját képző WFP létét megkérdőjelezték (44), illetve az IDEAL-vizsgálatban (45) a WPF-ban a rezisztencia magasabbnak bizonyult, mint hyperaemiában a teljes szívciklusban. Ezek alapján feltételezhető, hogy egyéb, nem a WFP-ban mért nyugalmi indexek (NHPR) hasonló diagnosztikus értékkel bírnak, mint az iFR, amelynek meghatározásához specifikus szoftverre van szükség és csak a Philips/Volcano konzollal mérhető (szemben a „generikus” FFR-rel).

Van't Veer vizsgálatában (46) a VERIFY 2-sudy során nyert görbéket újra elemezte, illetve vizsgálta, hogy különböző, mesterséges, de előre definiált nonhyperaemiás diasztolés indexek, illetve a teljes szívciklusban, nyugalomban mért $P_{d} / P_{a}$ hányados diagnosztikus értéke hogyan alakul az FFR-hez (0,80-as cut-off értéket alapul véve), illetve az iFR-hez (0,89-es vágóérték mel- lett) képest. A vizsgált nyugalmi diasztolés paraméterek a következők voltak:

- dPR: átlag $\mathrm{P}_{\mathrm{d}} / \mathrm{P}_{\mathrm{a}}$ a teljes diasztoléban,

- dPR25-75: átlag $\mathrm{P}_{\mathrm{d}} / \mathrm{P}_{\mathrm{a}}$ a diasztolé 25\%-tól a 75\%-ig,

- dPRmid: a diasztolé közepén, egyetlen pillanatban mért $P_{d} / P_{a}$,

- iFRmatlab: az iFR-komputerrel, az eredeti algoritmussal kiszámolt, nem pedig a Volcano konzollal mért értéke,

- iFR-50 ms: átlag $P_{d} / P_{a}$ a diasztolé 25\%-tól a vége előtt 50 ms-ig,

- iFR-100 ms: átlag $P_{d} / P_{a}$ a diasztolé 25\%-tól a vége előtt $100 \mathrm{~ms}$-ig.

A diasztolé kezdetét minden esetben a dikrot csomó nadírja jelezte; a meghatározások automata módon történtek öt egymást követő ütés átlagolása alapján. A vizsgált paramétereket a 3 . ábra mutatja.

A vizsgált paraméterek FFR-hez (cut-off 0,80 ) viszonyított diagnosztikus értékeit (0,89-es cut-off mellett) a 4. ábra mutatja. Az iFR-hez képest a különböző nyugalmi diasztolés nyomáshányadosok ROC-görbéit az 5. ábra mutatja. Mint látható, a ROC-görbék alatti terült (AUC) minden esetben 0,99 feletti, illetve a különböző nonhyperaemiás diasztolés nyomáshányadosok és az iFR közötti különbség megegyezett a két egymás utáni iFR-mérés között talált különbséggel, emellett a különböző nonhyperaemiás diasztolés nyomáshányadosok és az iFR minden szempontból (szenzitivitás, specificitás, pozitív, negatív prediktív érték, diagnosztikus pontosság) hasonlóan „teljesítenek” az FFRhez képest, cut-off értékük is megegyezik, így ezeket bioekvivalensnek kell tekintenünk és az iFR-re vonatkozó ajánlásokat érvényesnek kell tekintenünk ezekre is. A nyugalmi (nonhyperaemiás), teljes szívciklusban mért $P_{d} / P_{a}$ hányados diagnosztikus értéke is a fentiek-

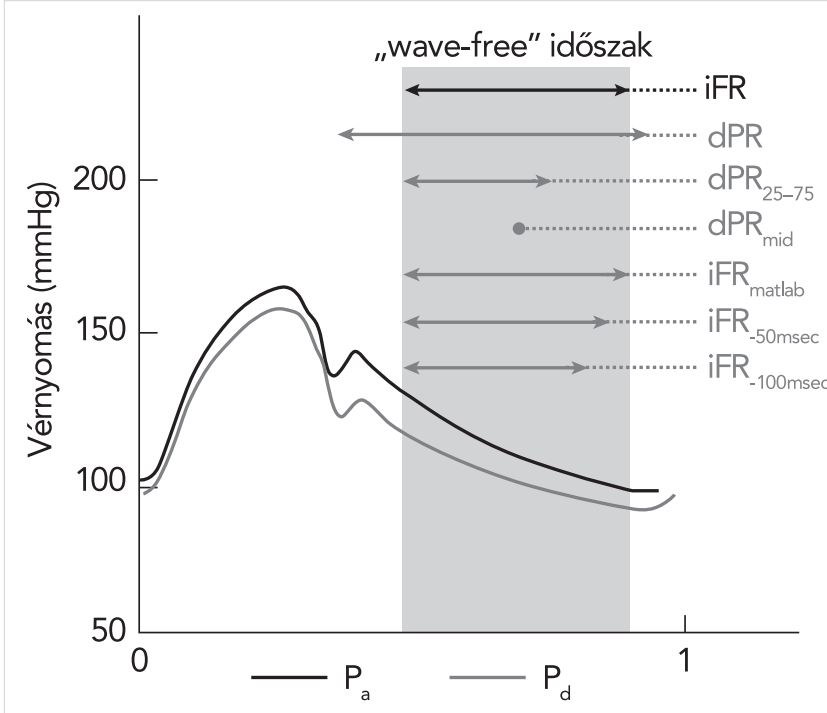

3. ÁBRA. Nonhyperaemiás diasztolés nyomáshányadosok van't Veer tanulmányában (46) 


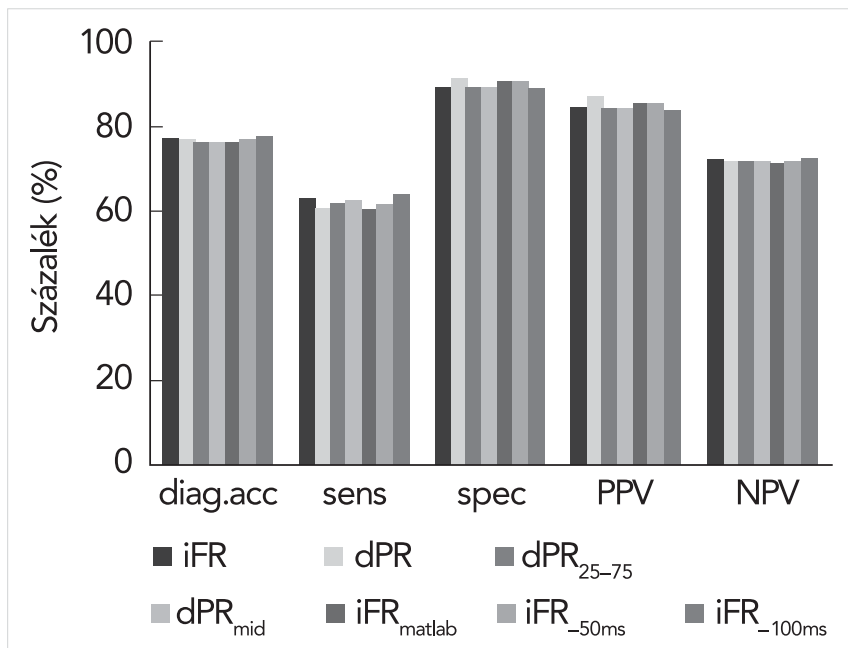

4. ÁBRA. A nonhyperaemiás diasztolés nyomáshányadosok diagnosztikus értéke FFR-hez képest van't Veer tanulmányában (46)

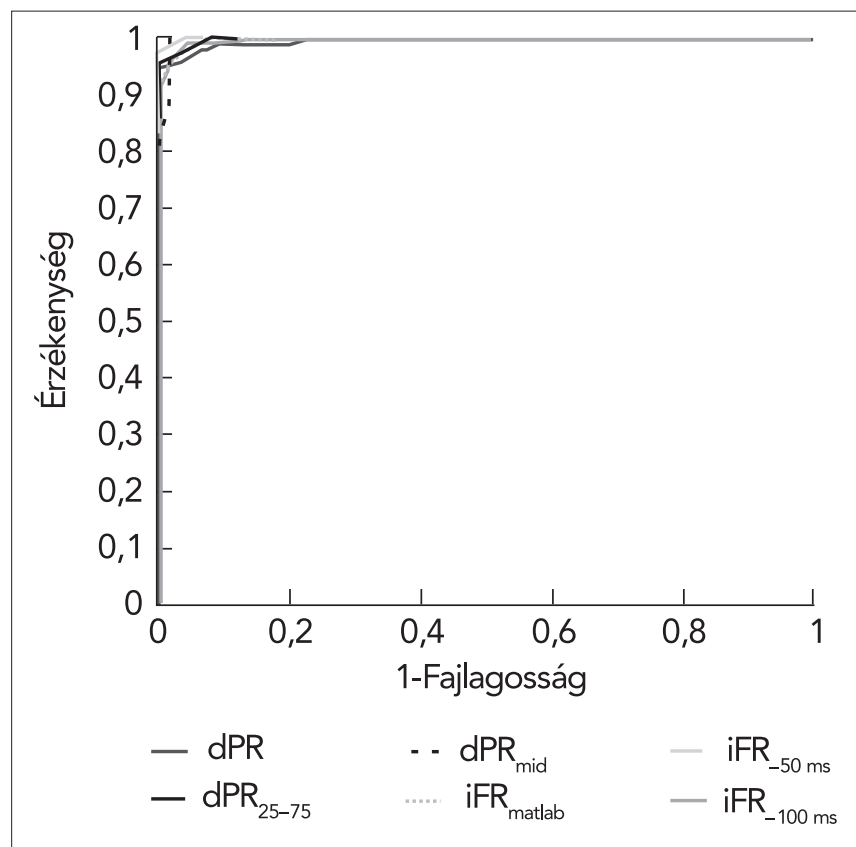

5. ÁBRA. A nonhyperaemiás diasztolés nyomáshányadosok ROC-görbéi az iFR-t referenciának véve van't Veer tanulmányában (46)

kel egyező, azokétól $(0,89)$ minimálisan eltérő cut-off értékkel $(0,91)$. Van't Veer és munkatársai egyben azt is igazolták, hogy a vizsgált összes nonhyperaemiás paraméter egyformán jól reprodukálható és egyformán változik hyperaemiás hatásra, amely ugyancsak megkérdőjelezi a WFP unikalitását.

Végül minden nyomásmérő vezetődrótot vagy mikrokatétert előállító cég megjelent saját nyugalmi indexével, a jelen gyakorlatban ezeket nevezzük NHPR-nak. Ezek többsége diasztolés (iFR, DFR, dPR, DPR), de van teljes szívciklusban mért (RFR) és természetesen ilyen a minden rendszer által mért nyugalmi $P_{d} / P_{a}$ hányados is.
Az Opsens algoritmusa a diasztolé kezdetét a dikrot csomó alapján határozza meg, nem szükséges hozzá EKG, és 4 konszekutív ütés teljes, nonhyperaemiás diasztoléjában mért $P_{d} / P_{a}$ hányados mediánjaként adja meg a diastolic pressure ratiot (dPR).

A Boston Scientific konzol által megadott diastolic pressure ratio (dPR) méréséhez nincs szükség sem EKG-ra, sem jól felismerhető dikrot csomóra (47). Az algoritmus két paraméter alapján határozza meg a diagnosztikus ablakot (a diasztolét) a dPR meghatározásához: az aktuális aortanyomás az átlagnál alacsonyabb és csökkenő tendenciát mutat. Az így meghatározott mintavételi ablakból származó $P_{d}$ és $P_{a}$ értékeket átlagolja öt egymást követő szívciklusban és hányadosukat $\left(\mathrm{P}_{\mathrm{d}} / \mathrm{P}_{\mathrm{a}}\right)$ definiálja dPR-ként. Így a dPR meghatározható akkor is, ha hiányzik vagy szuboptimális az EKG-görbe, vagy nem azonosítható a dikrot csomó az aortás nyomásgörbén.

Az Abbott-konzolokon mérhető resting full-cycle ratio (RFR) annyiban különleges, hogy a nyugalmi $P_{d} / P_{a}-h o z$ hasonlóan nem diasztolés, hanem teljes szívciklusban és nem hyperaemiában mért nyomáshányados (48). Az RFR-t min. 4, inkább 5 egymást követő szívciklusban a legalacsonyabb pillanatnyi $P_{d} / P_{a}$ értékként határozzák meg (miután a zajt megfelelő software-rel kiszűrték). Ezt mutatja a 6. ábra. A VALIDATE-RFR (48) vizsgálat első (derivációs) részében a VERIFY (31) és a CONTRAST (49) tanulmány individuális nyomásgörbéi alapján meghatározták az RFR optimális cut-off értékét a 0,80-as FFR-vágóértékhez képest. Ez 0,89-nek adódott. Ennél a vágóértéknél az RFR diagnosztikus pon-

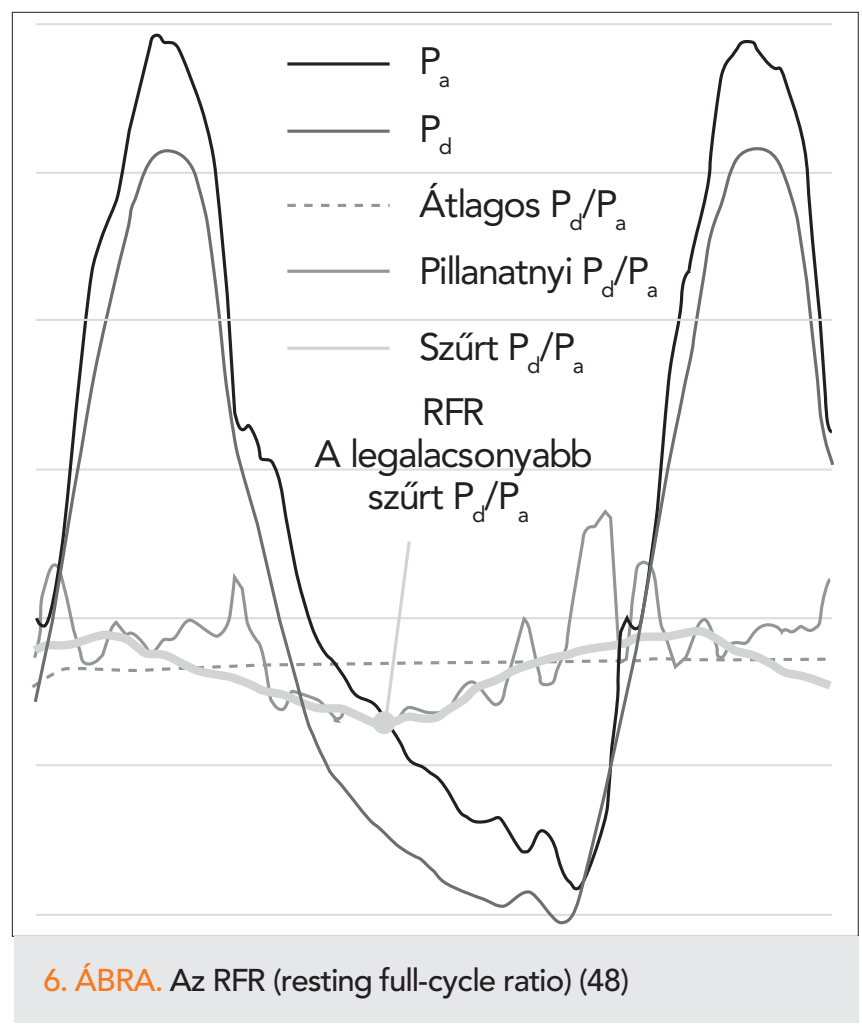


tossága az FFR-hez képest 78\%-nak bizonyult, amely megegyezik az egyéb NHPR-ével. A vizsgálat második (validációs) részében a VERIFY 2-vizsgálat (35) és az IRIS-FFR-regiszter (50) nyomásgörbéi elemzésével az RFR és az iFR egyezését vizsgálták. A vizsgálat megerősítette az RFR és az iFR diagnosztikus ekvivalenciáját (ROC AUC 0,996, átlagos különbség -0,002, konkordancia kappa 0,94). A VALIDATE-RFR-study különösen fontos megállapítása az volt, hogy az RFR a diasztolén kívülre esett a görbék 12,2\%-ban, így elvileg segítségével felismerhetők azok a szignifikáns léziók, amelyek iFR-rel nem szignifikánsnak bizonyultak. Minél magasabb az iFR, annál gyakoribb az, hogy az RFR a diasztolén kívül esik, illetve a jobb koronáriában gyakoribb, mint a bal koronáriában. A jobb koronáriában, szürke zónás iFR-érték $(0,86-0,93)$ mellett $6,5 \%$-ban fordult elö az, hogy az RFR nem a diasztoléra esett. Az RFR előnye, hogy meghatározásához nem szükséges sem EKG, sem egyéb jel, mert a mintavételi ablak a teljes szívciklus.

Összefoglalva elmondható, hogy az NHPR-k bioekvivalensnek tarthatók. Előnyük, hogy mérésükhöz nem szükséges sem adenozin, sem egyéb hyperaemiás ágens, ezáltal minimálisan gyorsítják a mérési időt, csökkentik a beteg (átmeneti, ártalmatlan) diszkomfort érzetét, azonban diagnosztikus pontosságuk az FFRhez képest kb. 80\% (bioekvivalenciát az NHPR-k és az FFR között sohasem mutattak ki). Az NHPR-k és az FFR közti diszkrepancia prognosztikailag fontos, proximális nagyerekben, fiatal, egészséges mikrovaszkulatúrával bíró egyénekben még nagyobb lehet. Az NHPR-ek alacsonyabb jel-zaj aránnyal járnak, amely nagyobb drifttel járó nyomásmérő vezetődrótok esetén kifejezettebb pontatlanságot eredményezhet. Emellett NHPR kizárólagos használata mellett nem lehetséges a $\mathrm{PCl}$ utáni eredmény lemérése fiziológiai szempontból, mert, főként komplex $\mathrm{PCl}$ után, elhúzódóan részleges hyperaemia marad fenn. Ezen gondok egy részére a megoldást a részleges hyperaemiát okozó kontrasztanyaggal történt, ún. kontraszt FFR (cFFR) meghatározás jelenti.

\section{cFFR}

Már 1959-ben leírásra került, hogy állatokban a kontrasztanyag adása hyperaemiát eredményez (51), emberben pedig 1974-ben használták a szükület patofiziológiai hatásának lemérésére (52). Johnson és munkatársai (49) a 750 beteg bevonásával elvégzett CONTRAST-studyban azt találták, hogy a kontrasztanyag-okozta, szubmaximális hyperaemiával mért „FFR”, a kontraszt FFR (cFFR) optimális cut-off értéke 0,83 (FFR-hez képest, 0,80-as vágóérték mellett), emellett a cFFR diagnosztikus pontossága az FFR-hez képest $85 \%$, amely a vizsgálatban szignifikánsan magasabb volt, mint az iFR-é, illetve a nyugalmi $\mathrm{P}_{\mathrm{d}} / \mathrm{P}_{\mathrm{a}}$-é (amelyeké 78-79\%-nak bizonyult), ROC AUC-je 0,93 volt, amely szignifikánsan meghaladta az iFR-ét $(0,881)$ és a nyugalmi $P_{d} / P_{a}$-ét $(0,875)$, utóbbi kettő között nem volt szignifikáns különbség. A megismételt cFFR-mérések eredményei közti szórás szignifikánsan kisebbnek bizonyult, mint akár az iFR-é, akár a nyugalmi $P_{d} / P_{a}$-é, azaz a hyperaemia növelésével csökken a szórás. Megemlítendő, hogy a cFFR-méréshez bármely kereskedelmi forgalomban elérhető kontrasztanyagot megengedtek (végül a vizsgálók 8 félét használtak), az átlagos kontrasztanyag „dózis” $8 \mathrm{ml}$ volt.

A fentiek alapján elmondható, hogy amennyiben az adenozin nem hozzáférhető, vagy kontraindikált (nagyon ritka eset), vagy valamely okból az operatőr nem kíván hyperaemiás ágenst használni, a kontrasztanyag adásával elért részleges hyperaemiában mért cFFR elönyös az NHPR-ekhez képest.

\section{Ko̊vetkeztetések}

A hyperaemia „megspórolásával” végzett intrakoronáriás fiziológiai vizsgálatok vonzóak egyszerűbb, kissé gyorsabb és minimálisan olcsóbb voltukból adódóan. Ugyanakkor minél kevésbé hyperaemiás körülmények között vizsgáljuk a koronáriaszűkületek funkcionális hatását, annál jobban sérül a diagnosztikus pontosság, és a tisztán nyugalomban történt meghatározással az már csak $80 \%$-os. Ennek klinikai jelentősége kis kockázatú betegcsoporton a nagy randomizált vizsgálatokban elenyésző, de nagyobb kockázat mellett nem ismert, potenciálisan jelentős. Az aranystandard FFR alkalmazásával az elmúlt 20 év számos vizsgálata alapján jobban kiválaszthatók azok a léziók, amelyek revaszkularizációjából a betegnek tüneti vagy prognosztikus előnye származik, elkerülhetők a fölösleges $\mathrm{PCl}-\mathrm{k}$ (16-20, 25-27), megítélhető az elvégzett PCI funkcionális eredménye, amely prognosztikai értékkel bír (53, 54). Magyarországon abban a szerencsés helyzetben vagyunk, hogy az FFR-mérés finanszírozott, az adenozin hozzáférhető és ára alapján elérhető, így intrakoronáriás nyomásmérés és a szűkületek funkcionális meghatározása kapcsán nem kényszerülünk kompromisszumra. Klinikai döntéshozatalunkban támaszkodjunk az aranystandard FFR-re, és NHPR-mérés negatív eredménye alapján ne hozzunk olyan döntést, hogy a revaszkularizáció az adott esetben biztosan szükségtelen, főleg, ha a lézió prognosztikailag fontos lokalizációban van (fötörzs, proximális LAD, proximális, domináns RCA).

\footnotetext{
Irodalom

1. Mangiacapra F, Barbato E. From SYNTAX to FAME, a paradigm shift in revascularization strategies: the key role of fractional flow reserve in guiding myocardial revascularization. J Cardiovasc Med 2011; 12: 538-542. doi: 10.2459/JCM.0b013e328347edc3 2. Pijls NHJ, van Son JAM, Kirkeeide RL, Be Bruyne B, Gould KL.
} 
Experimental basis of determining maximum coronary, myocardial and collateral blood flow by pressure measurement for assessing functional stenosis severity before and after percutaneous transluminal coronary angioplasty. Circulation 1993; 86: 1354-1367. https://doi.org/10.1161/01.CIR.87.4.1354

3. Pijls NHJ, De Bruyne B, Peels K, van der Voort PH, Bonnier HJRM, et al. Measurement of fractional flow reserve to assess the functional severity of coronary-artery stenoses. N Engl J Med 1996; 334: 1703-1708. DOI: 10.1056/NEJM199606273342604

4. Pijls NHJ, De Bruyne B, Bech GJW, Liistro F, Heyndrickx GR et al. Coronary pressure measurement to assess the hemodynamic significance of serial stenosis within one coronary artery: validations in humans. Circulation 2000; 102: 2371-2377. https://doi. org/10.1161/01.CIR.102.19.2371

5. De Bruyne B, Baudhuin T, Melin JA, Pijls NHJ, Sys SU, Bol A, et al. Coronary flow reserve calculated from pressure measurements in humans. Validation with positron emission tomography. Circulation 1994; 89: 1013-1022. https://doi.org/10.1161/01.CIR.89.3.1013 6. Jiménez-Navarro M, Alonso-Briales JH, Hernández García MJ, Bailón IR, Gómez-Doblas JJ, De Teresa Galván E. Measurement of fractional flow reserve to assess moderately severe coronary lesions: correlation with dobutamine stress echocardiography. J Interv Cardiol 2001; 14: 499-504. https://doi.org/10.1111/j.1540-8183.2001. tb00365 $x$

7. De Bruyne B, Pijls NHJ, Bartunek J, Kulecki K, Bech JW, et al Fractional flow reserve in patients with prior myocardial infarction. Circulation 2001; 104: 157-162. https://doi.org/10.1161/01 CIR.104.2.157

8. Berger A, Botman KJ, MacCarthy PA, Wijns W, Bartunek J, et al. Long-term clinical outcome after fractional flow reserve-guided percutaneous coronary intervention in patients with multivessel disease. J Am Coll Cardiol 2005; 46: 438-442. DOI: 10.1016/j. jacc.2005.04.041

9. Koo BK, Kang HJ, Youn TJ, Chae IH, Choi DJ, et al. Physiologic assessment of jailed side branch lesions using fractional flow reserve. J Am Coll Cardiol 2005; 46: 633-637. DOI: 10.1016/j. jacc.2005.04.054

10. Hamilos M, Muller O, Cuisset T, Ntalianis A, Chlouverakis G, et al. Long-term clinical outcome after fractional flow reserve-guided treatment in patients with angiographically equivocal left main coronary artery stenosis. Circulation 2009; 120: 1505-1512. https://doi. org/10.1161/CIRCULATIONAHA.109.850073

11. Ntalianis A, Sels JW, Davidavicius G, Tanaka N, Muller O, et al. Fractional flow reserve for the assessment of nonculprit coronary artery stenoses in patients with acute myocardial infarction. $J$ Am Coll Cardiol Cardiovasc Intv 2010; 3: 1274-1281. DOI: 10.1016/j. jcin.2010.08.025

12. Muller $\mathrm{O}$, Mangiacapra F, Ntalianis $A$, Verhamme KM, Trana $C$, et al. Long-term follow-up after fractional flow reserve-guided treatment strategy in patients with an isolated proximal left anterior descending coronary artery stenosis. J Am Coll Cardiol Cardiovasc Interv 2011; 4: 1175-1182. DOI: 10.1016/j.jcin.2011.09.007

13. Puymirat E, Peace A, Mangiacapra F, Conte M, Ntarladimas $Y$, et al. Long-term clinical outcome after fractional flow reserve-guided percutaneous coronary revascularization in patients with small-vessel disease. Circ Cardiovasc Interv 2012; 5: 62-68. DOI: 10.1161/ CIRCINTERVENTIONS.111.966937

14. Fearon WF, Hirohata A, Nakamura M, Luikart H, Lee DP, et al. Discordant changes in epicardial and microvascular coronary physiology after cardiac transplantation: Physiologic Investigation for Transplant Arteriopathy II (PITA II) Study. J Heart Lung Transplant 2006; 25: 765-771. doi:10.1016/j.healun.2006.03.003

15. Koo BK, Park KW, Kang HJ, Cho YS, Chung WY, et al. Physiological evaluation of the provisional side-branch intervention strategy for bifurcation lesions using fractional flow reserve. Eur Heart $J$
2008; 29: 726-732. https://doi.org/10.1093/eurheartj/ehn045 16. Bech GJ, De Bruyne B, Pijls NHJ, de Muinck ED, Hoorntje $\mathrm{JCA}$, et al. Fractional flow reserve to determine the appropriateness of angioplasty in moderate coronary stenosis: a randomized trial. Circulation 2001; 103: 2928-2934. https://doi.org/10.1161/01. CIR.103.24.2928

17. Pijls NHJ, van Schaardenburgh P, Manoharan G, Boersma E, Bech JW, et al. Percutaneous Coronary Intervention of Functionally Nonsignificant Stenosis. 5-Year Follow-Up of the DEFER Study. J Am Coll Cardiol 2007; 49: 2105-2111. DOI: 10.1016/j.jacc.2007.01.087

18. Tonino PAL, De Bruyne B, Pijls NHJ, Siebert U, Ikeno F, et al. Fractional flow reserve versus angiography for guiding percutaneous coronary intervention. N Engl J Med 2009; 360: 213-224. DOI: 10.1056/NEJMoa0807611

19. Pijls NHJ, Fearon WF, Tonino PA, Siebert U, Ikeno F, et al. Fractional flow reserve versus angiography for guiding percutaneous coronary intervention in patients with multivessel coronary artery disease: 2-year follow-up of the FAME (Fractional Flow Reserve Versus Angiography for Multivessel Evaluation) study. J Am Coll Cardiol 2010; 56: 177-184. doi:10.1016/j.jacc.2010.04.012

20. van Nunen LX, Zimmermann FM, Tonino PAL, Barbato E, Baumbach $A$, et al. Fractional flow reserve versus angiography for guidance of $\mathrm{PCl}$ in patients with multivessel coronary artery disease (FAME): 5-year follow-up of a randomised controlled trial. Lancet 2015; 386: 1853-1860. https://doi.org/10.1016/S0140-6736(15)00057-4

21. Wijns W, Kohl P, Danchin N, Di Mario C, Falk V, et al. Guidelines on myocardial revascularization. The Task Force on Myocardial Revascularization of the European Society of Cardiology (ESC) and the European Association for Cardio-Thoracic Surgery (EACTS). Eur Heart J 2010; 31: 2501-2555. doi:10.1093/eurheartj/ehq277

22. Windecker S, Kohl P, Alfonso F, Collet JP, Cremer J, et al. 2014 ESC/EACTS Guidelines on myocardial revascularization. The Task Force on Myocardial Revascularization of the European Society of Cardiology (ESC) and the European Association for Cardio-Thoracic Surgery (EACTS). Developed with the special contribution of the European Association of Percutaneous Cardiovascular Interventions (EAPCI). Eur Heart J 2014; 35: 2541-2619. doi: 10.1093/eurheartj/ehu278

23. Neumann FJ, Sousa-Uva M, Ahlsson A, Alfonso F, Banning AP, et al. The Task Force on myocardial revascularization of the ESC and EACTS. 2018 ESC/EACTS Guidelines on myocardial revascularization. Eur Heart J 2018; 00: 1-96. https://doi.org/10.1093/eurheartj/ehy394

24. Knuuti J, Wijns W, Saraste A, Capodanno D, Barbato E, et al. 2019 ESC Guidelines for the diagnosis and management of chronic coronary syndromes. The Task Force for the diagnosis and management of chronic coronary syndromes of the European Society of Cardiology (ESC) Eur Heart J 2019; 00: 1-71 doi:10.1093/eurheartj/ ehz425

25. Zimmermann FM, Ferrara A, Johnson NP, van Nunen LX, Escaned J, et al. Deferral vs. performance of percutaneous coronary intervention of functionally non-significant coronary stenosis: 15year follow-up of the DEFER trial. Eur Heart J 2015; 36: 3182-3188. doi: 10.1093/eurheartj/ehv452

26. De Bruyne B, Pijls NH, Kalesan B, Barbato E, Tonino PA, et al. FAME 2 Trial Investigators. Fractional flow reserve-guided $\mathrm{PCl}$ versus medical therapy in stable coronary disease. N Engl J Med 2012; 367: 991-1001. DOI: 10.1056/NEJMoa1205361

27. De Bruyne B, Fearon WF, Pijls NH, Barbato E, Tonino PAL, et al. FAME 2 Trial Investigators. Fractional flow reserve-guided $\mathrm{PCl}$ for stable coronary artery disease. N Engl J Med 2014; 371: 1208-1217. DOI: 10.1056/NEJMoa1408758

28. Johnson NP, Koo BK. Coronary physiology. Do you believe? J Am Coll Cardiol Cardiovasc Interv 2018; 11: 1492-1494. DOI: 10.1016/j.jcin.2018.05.021 
29. Mamas MA, Horner S, Welch E, Ashworth A, Millington S, et al. Resting $\mathrm{Pd} / \mathrm{Pa}$ measured with intracoronary pressure wire strongly predicts fractional flow reserve. J Invasive Cardiol 2010; 22: 260 265. http://hdl.handle.net/10993/27826

30. Sen S, Escaned J, Malik IS, Mikhail GW, Foale RA, et al. Development and validation of a new adenosine-independent index of stenosis severity from coronary wave-intensity analysis: results of the ADVISE (ADenosine Vasodilator Independent Stenosis Evaluation) study. J Am Coll Cardiol 2012; 59: 1392-1402. DOI: 10.1016/j. jacc.2011.11.003

31. Berry C, van 't Veer M, Witt N, Kala P, Bocek O, Pyxaras SA, McClure JD, Fearon WF, Barbato E, Tonino PA, De Bruyne B, Pijls $\mathrm{NH}$, Oldroyd KG. VERIFY (VERification of Instantaneous Wave-Free Ratio and Fractional Flow Reserve for the Assessment of Coronary Artery Stenosis Severity in EverydaY Practice): a multicenter study in consecutive patients. J Am Coll Cardiol 2013; 61: 1421-7. DOI: 10.1016/j.jacc.2012.09.065

32. Seiler C, Kirkeeide RL, Gould KL. Basic structure-function relations of the epicardial coronary vascular tree. Basis of quantitative coronary arteriography for diffuse coronary artery disease. Circulation 1992; 85: 1987-2003. https://doi.org/10.1161/01. CIR.85.6.1987

33. Escaned J, Echavarría-Pinto M, Garcia-Garcia HM, van de Hoef TP, de Vries T, et al. II, Study G. Prospective assessment of the diagnostic accuracy of instantaneous wave-free ratio to assess coronary stenosis relevance: results of ADVISE II international, multicenter study (Adenosine Vasodilator Independent Stenosis Evaluation II). J Am Coll Cardiol Cardiovasc Interv 2015; 8: 824-833. doi: 10.1016/j. jcin.2015.01.029

34. Petraco R, Park JJ, Sen S, Nijjer SS, Malik IS, et al. Hybrid iFRFFR decision-making strategy: implications for enhancing universal adoption of physiology-guided coronary revascularisation. Eurolntervention 2013; 8: 1157-65. DOI: 10.4244/EIJV8I10A179

35. Hennigan B, Oldroyd KG, Berry C, Johnson N, McClure J, et al. Discordance between resting and hyperemic indices of coronary stenosis severity: the VERIFY 2 study (a comparative study of resting coronary pressure gradient, instantaneous wave-free ratio and fractional flow reserve in an unselected population referred for invasive angiography). Circ Cardiovasc Interv 2016; 9. pii: e004016. https://doi.org/10.1161/CIRCINTERVENTIONS.116.004016

36. Jeremias A, Maehara A, Généreux $P$, Asrress KN, Berry C, et al. Multicenter core laboratory comparison of the instantaneous wave-free ratio and resting $\mathrm{Pd} / \mathrm{Pa}$ with fractional flow reserve: the RESOLVE study. J Am Coll Cardiol 2014; 63: 1253-1261. https://doi. org/10.1016/j.jacc.2013.09.060

37. Davies JE, Sen S, Dehbi HM, Al-Lamee R, Petraco R, et al. Use of the instantaneous wave-free ratio or fractional flow reserve in $\mathrm{PCI}$ N Engl J Med 2017; 376: 1824-1834. DOI: 10.1056/NEJMoa1700445 38. Götberg M, Christiansen EH, Gudmundsdottir IJ, Sandhall L, Danielewicz M, et al. iFR-SWEDEHEART Investigators. Instantaneous wave-free ratio versus fractional flow reserve to guide $\mathrm{PCI}$. N Engl J Med 2017; 376: 1813-1823. doi: 10.1056/NEJMoa1616540

39. Davies JE on behalf of the DEFINE FLAIR investigators. iFR vs. FFR for guiding coronary revascularization. DEFINE FLAIR (2 year results) TCT 2019

40. Götberg M. 2-year outcome data from DEFINE FLAIR and SWEDEHEART: A critical appraisal. TCT 2019

41. Kobayashi Y, Johnson NP, Berry C, De Bruyne B, Gould KL, et al. on behalf of the CONTRAST Study Investigators. The influence of lesion location on the diagnostic accuracy of adenosine-free coronary pressure wire measurements. J Am Coll Cardiol Cardiovasc Intv 2016; 9: 2390-2399. DOI: 10.1016/j.jcin.2016.08.041

42. Patel MR, Calhoon JH, Dehmer GJ, Grantham JA, Maddox TM, et al. Corrections to ACC/AATS/AHA/ASE/ASNC/SCAI/SCCT/ STS 2017 Appropriate Use Criteria for Coronary Revascularization in $\mathrm{Pa}$ tients With Stable Ischemic Heart Disease: A Report of the American College of Cardiology Appropriate Use Criteria Task Force, American Association for Thoracic Surgery, American Heart Association, American Society of Echocardiography, American Society of Nuclear Cardiology, Society for Cardiovascular Angiography and Interventions, Society of Cardiovascular Computed Tomography, and Society of Thoracic Surgeons J Am Coll Cardiol 2018; 71: 2279 2280 DOI: 10.1016/j.jacc.2018.03.453

43. Berry C, McClure JD, Oldroyd KG. Meta-Analysis of Death and Myocardial Infarction in the DEFINE-FLAIR and iFR-SWEDEHEART Trials. Circulation 2017; 136: 2389-91 https://doi.org/10.1161/CIRCULATIONAHA.117.030430

44. Westerhof N, Segers P, Westerhof BE. Wave separation, wave intensity, the reservoir-wave concept, and the instantaneous wave-free ratio: novelty and significance. Hypertension 2015; 66: 93-8. https://doi.org/10.1161/HYPERTENSIONAHA.115.05567

45. Nijjer SS, de Waard GA, Sen S, van de Hoef TP, Petraco R, et al. Coronary pressure and flow relationships in humans: phasic analysis of normal and pathological vessels and the implications for stenosis assessment: a report from the Iberian-Dutch-English (IDEAL) collaborators. Eur Heart J 2016; 37: 2069-80. doi: 10.1093/ eurheartj/ehv626

46. Van't Veer M, Pijls NHJ, Hennigan B, Watkins S, Ali ZA, et al. Comparison of Different Diastolic Resting Indexes to iFR: Are They All Equal? J Am Coll Cardiol 2017; 70: 3088-96. DOI: 10.1016/j. jacc.2017.10.066

47. Johnson NP, Li W, Chen X, Hennigan B, Watkins S, et al. Diastolic pressure ratio: new approach and validation vs. the instantaneous wave-free ratio. Eur. Heart J 2019; 40: 2585-2594 doi:10.1093/eurheartj/ehz230

48. Svanerud J, Ahn JM, Jeremias A, van 't Veer M, Gore A, et al. Validation of a novel non-hyperaemic index of coronary artery stenosis severity: the Resting Full-cycle Ratio (VALIDATE RFR) study. Eurolntervention 2018; 14: 806-814. DOI:10.4244/eij-d-18-00342 49. Johnson NP, Jeremias A, Zimmermann FM, Adjedj J, Witt N, et al. Continuum of Vasodilator Stress From Rest to Contrast Medium to Adenosine Hyperemia for Fractional Flow Reserve Assessment. J Am Coll Cardiol Cardiovasc Interv 2016; 9: 757-67. DOI: 10.1016/j. jcin.2015.12.273

50. Ahn JM, Park DW, Shin ES, Koo BK, Nam CW, et al. Fractional Flow Reserve and Cardiac Events in Coronary Artery Disease: Data From a Prospective IRIS-FFR Registry (Interventional Cardiology Research Incooperation Society Fractional Flow Reserve). Circulation 2017; 135: 2241-51. doi: 10.1161/CIRCULATIONAHA.116.024433

51. Guzman SV, West JW. Cardiac effects of intracoronary arterial injections of various roentgenographic contrast media. Am Heart $J$ 1959; 58: 597-607. DOI: 10.1016/0002-8703(59)90095-x

52. Gould KL, Hamilton GW, Lipscomb K, Ritchie JL, Kennedy JW. Method for assessing stress-induced regional malperfusion during coronary arteriography. Experimental validation and clinical application. Am J Cardiol 1974; 34: 557-64. DOI: 10.1016/00029149(74)90127-1

53. Piroth Z, Toth GG, Tonino PAL, Barbato E, Aghlmandi S, et al. Prognostic Value of Fractional Flow Reserve Measured Immediately After Drug-Eluting Stent Implantation. Circ Cardiovasc Interv 2017; 10: e005233. DOI: 10.1161/CIRCINTERVENTIONS.116.005233.

54. Johnson NP, Tóth GG, Lai D, Zhu H, Açar G, et al. Prognostic value of fractional flow reserve: linking physiologic severity to clinical outcomes. J Am Coll Cardiol 2014; 64: 1641-1654. https://doi. org/10.1016/j.jacc.2014.07.973 